\title{
アスベスト含有セメント板中のアスベストの機械的粉砕
}

橋本 忍·山口明良* · 本多沢雄 ·淡路英夫 ·福田功一郎

名古屋工業大学環境材料工学科, 466-8555 名古屋市昭和区御器所町

*岡山セラミックス技術振興財団研究所, 705-0021 備前市西片上 1406-18

\section{Comminution of Asbestos by a Mechanical Grinding in Asbestos-Containing Cement Board}

\author{
Shinobu HASHIMOTO, Akira YAMAGUCHI, * Sawao HONDA, Hideo AWAJI and Koichiro FUKUDA
}

Department of Invironmental and Materials Engineering, Nagoya Institute of Technology, Gokiso-cho, Showa-ku, Nagoya-shi 466-8555 *Okayama Ceramics Research Foundation Research Laboratory, 1406-18, Nishi Katakami, Bizen-shi 705-0021

\begin{abstract}
When 10-20 mass \% of asbestos (chrysotile: $\mathrm{Mg}_{3} \mathrm{Si}_{2} \mathrm{O}_{5}(\mathrm{OH})_{4}$ ) -containing cement board of 5 mm thickness was heated at $600^{\circ} \mathrm{C}$ for $2 \mathrm{~h}$, the asbestos lost the crystal structure due to its dehydration reaction in the cement board, changing to an amorphous phase. Further, the heated cement board could be easily ground to grains with several $\mu \mathrm{m}$ size using a mortar. Then the asbestos seemed to be ground to below the size at the same time, because the fiber shape of original asbestos was not found in the sample.
\end{abstract}

[Received August 22, 2005; Accepted October 20, 2005]

Key-words : Asbestos, Chrysotile, Mechanical grinding, Heat treatment, Cement board

\section{1. 緒 言}

これまでにわが国に輸入されたアスベスト（石綿）の総量は， 白石綿（クリソタイル），青石綿（クロシドライト），茶石綿 （アモサイト）などの種類を区別しないで財務省輸入統計を単 純積算した場合，抢よそ1千万トンに達する。そのうち $100 \%$ を 超える量が鉄骨に対する吹き付けやセメント板など建築材とし て使用されてきた，労働安全衛生法関係政省令等の改正により 1995年に毒性の高い青石綿, 茶石綿の使用が禁止とされてから は，白石綿（クリソタイル : $\left.\mathrm{Mg}_{3} \mathrm{Si}_{2} \mathrm{O}_{5}(\mathrm{OH})_{4}\right)$ のみがカナダか ら主に輸入され，2000年で10万トン弱，ここ数年でも毎年 2〜 5 万トン，2004年には 8000 トンの輸入があった。2004年は大手 建材メーカーのアスベスト使用禁止の自主規制により輸入量が 大幅に減った。その労働安全衛生法施行令の一部改正により 2004年10月には，アスベストの原則禁止が打ち出された。しか しそれはこれまでにアスベスト含有量の特に高かった「緘維強 化セメント板」や「ブレーキパッド」など特定10品目に対し, 1 mass\%以上含有してはならないというもので，それ以外の品 目は除外されており，何よりクリソタイルの輸入そのものが禁 止されたわけではなかった。しかしながら今後，厚生労働省の 方針により2008年あるいは前倒してアスベストは全面使用禁止 になるものとみられる.

アスベストに関する規制として作業者保護の立場から，1975 年の労働安全衛生法令でいち早く「吹き付けアスベスト」の原 則禁止が打ち出された．1987年には，学校教育施設にその「吹 き付けアスベスト」が使われていることが分かり，いわゆる 「学校パニック」とよばれて社会問題化したが，その調査と撤 去という行政指導による対応により，アスベスト問題は一旦沈 静化したかにみえた。しかし2005年，肺や，心筋，腹膜などの 粘膜のがんの一種である「悪性中皮種」の原因が，作業現場な ぞで数十年前のアスベストの吸入による ${ }^{1)}$ という労災認定問題 が大きく取り上げられ，あらたな「公害」認定を視野に入れな がら，再び社会の関心がアスベスト問題に向けられるように なった。この飛散性の高い「吹き付けアスベスト」の撤去及び その処理に関しては，1988年の旧厚生省のガイドラインにより
撤去作業はマニュアル化され, 特別管理産業廃棄物として管理 型廃棄物最終処分場で埋め立て処理されている.しかしながら 非飛散性のアスベスト含有セメント板に関しては，撤去の際に アスベストを飛散させないことや，またその運搬や保管に際し 囲いや表示の義務がある程度である，廃棄物として処理する場 合には, セメントで固定化されており安全であるという理由か ら，ほとんど一般廃棄物と同じ扱いとなっている．今後はセメ ントの風化や破砕によるアスベストの露出や飛散など, アスベ スト含有セメント板も廃棄物としての安全性の問題が指摘さ れ，管理型の廃棄処分が要求されるものとみられる.

これから先の 2020 年前後には, セメント板など国内に数千万 トンあるアスベスト含有建築材の廃棄量がピークとなるといわ れている. 埋め立て処理をするにも，あるいは有効活用するた めにも, セメント板を始めとする「非飛散性」とされるアスべ スト含有建築材の安全な処理技術を確立することは急務なこと であると考える.

著者らは最近，クリソタイルのみに対する簡便な熱処理と粉 砕処理により，健康障害の原因であるクリソタイルの繊維状形 態を, Stanton らの提唱した健康を害する危険サイズ : 長さ 8 $\mu \mathrm{m}$ 以上, 径 $0.25 \mu \mathrm{m}$ 以下 $\left.^{2}\right)$ より小さくできることを見いだし報 告した ${ }^{3)}$. 本研究では, 実際にセメント板に強化材として加え られているアスベスト（クリソタイル）が，同様な熱処理と粉 砕により, 安全な大きさまでに破壊されるのかを, また化学組 成の変化と併せて，それを検証することを目的とした．

\section{2. 実験方法}

実験に使用したアスベスト含有セメント板は JIS A5423適合 品で，アスベスト (クリソタイル) 含有量は質量比で10～20\%, 厚さ $5 \mathrm{~mm}$ の民間家屋の屋根に用いられていたスレートと呼ば れる製品で，アスベスト製品であることを示す「a」の表示が ある，以後，アスベストはクリソタイル自身を指すので，本論 文中ではクリソタイルと記す。はじめにクリソタイルの微細形 態を知っておくために, 図 1 には代表的なカナダケベック州産 のクリソタイルの走査型電子顕微鏡（SEM； JSM5200, JEOL 

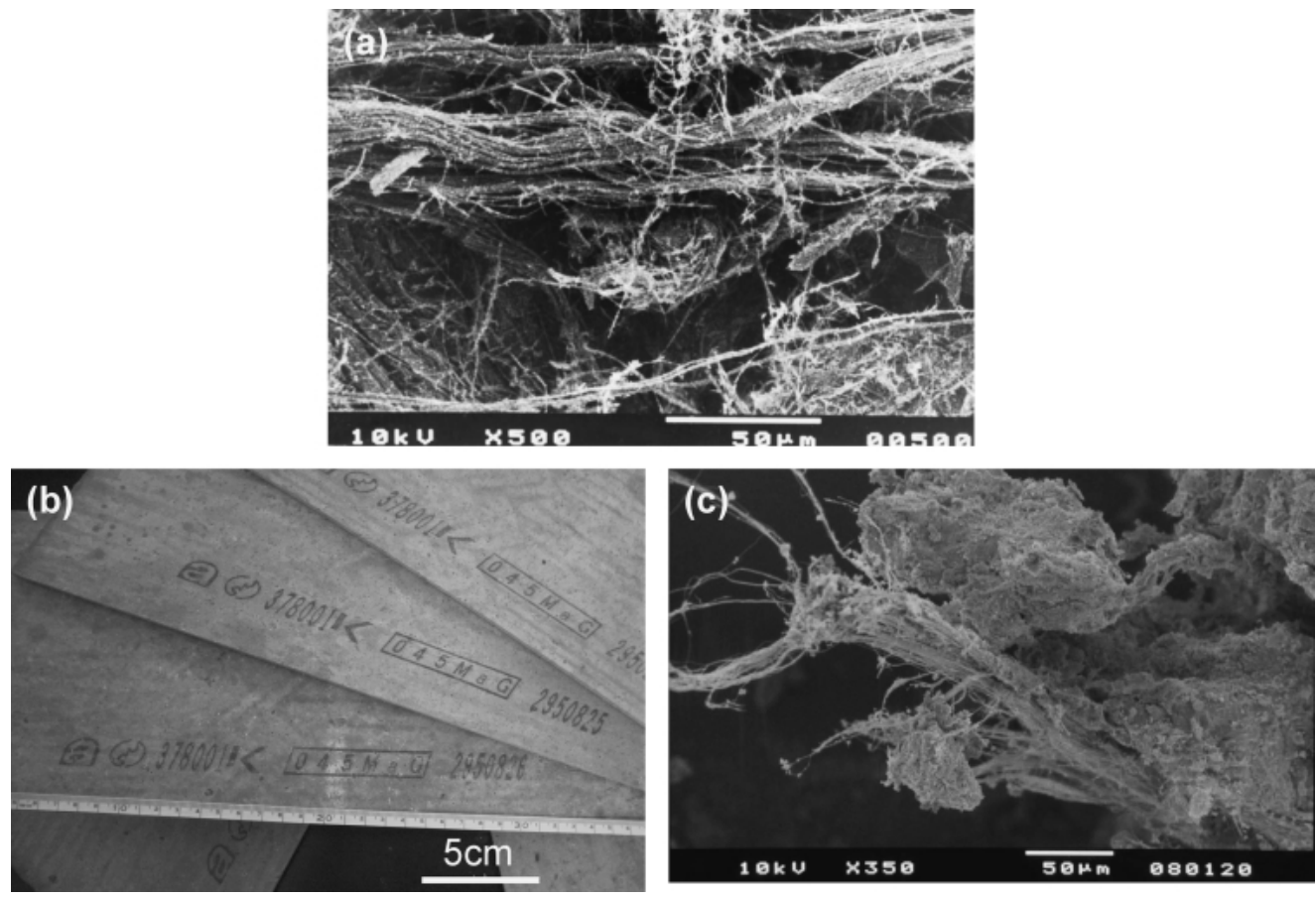

Fig. 1. SEM micrograph of Canadian chrysotile (a), appearance of chrysotile-containing cement board (b), and SEM micrograph of the fractured surface of the cement board (c).

製）観察写真，本実験で使用したクリソタイル含有セメント板 の概観，及びそのセメント板の破断面に抢ける SEM 観察写真 を示す．この写真のようにセメント板の破断面には，クリソタ イルの繊維状結晶がむき出しになった状態が多く観察された. セメント板が繊維強化されている様子が同えるとともに，破断 すれば簡単にクリソタイルが露出してしまうことを示している.

そのセメント板から $10 \times 10 \mathrm{~mm}$ (厚さ $5 \mathrm{~mm}$ ) の大きさに切り 出し, 実験に供する試料とした。試料を電気炉に入れ, $600^{\circ} \mathrm{C}$ の温度で $0 \sim 3 \mathrm{~h}$ 加熱保持した．この $600^{\circ} \mathrm{C}$ という温度はクリソ タイルのみの場合に効果のあった温度である ${ }^{3)}$. 昇温速度は 600 ${ }^{\circ} \mathrm{C} / \mathrm{h}$ とし, 加熱後電源を OFF にして試料は室温まで自然放冷 した．加熱後各試料の表面及び内部に分けて，X 線分析装置 （XRD；島津製作所製，XD-D1）で構成結晶相の分析を行っ た. 表面の分析では試料表面に X 線を直接入射して回折パ ターンを測定し, 内部の分析では粉挽処理した粉末試料に対し て回折パターンを測定した. 比較のために非加熱処理試料につ いても表面及びその内部についてXRD 分析を行った.

粉砕処理は, 試料を熱処理した後, アルミナ製乳鉢に入れて 粉砕した. 軽く数秒印いて粗砕し, その後クリソタイルのみを 粉碎処理した場合と同様に, 乳鉢と乳棒には常時 $2 \sim 3 \mathrm{~kg}$ の荷 重を掛けながら毎秒 $1 \sim 2$ 回転の速度で 2 3 min, セメント成 分もろとも粉砕した. 粉砕された試料をSEM で観察すること により，その試料内部に繊維状粒子（残存クリソタイル）が存 在するかを確認した。

\section{3. 結果と考察}

図 2 には, 図 1 のカナダ産クリソタイル及び本実験で用いた セメント板の熱処理を施していない試料の粉末 X 線回折結果を 示す．結果より，セメント板試料にクリソタイルが含まれてい ることが確認できた。 また結晶相としては他に， $\mathrm{SiO}_{2}$ (quartz) と $\mathrm{CaCO}_{3}$ (calcite) が検出されたが, セメントの水和硬化体と

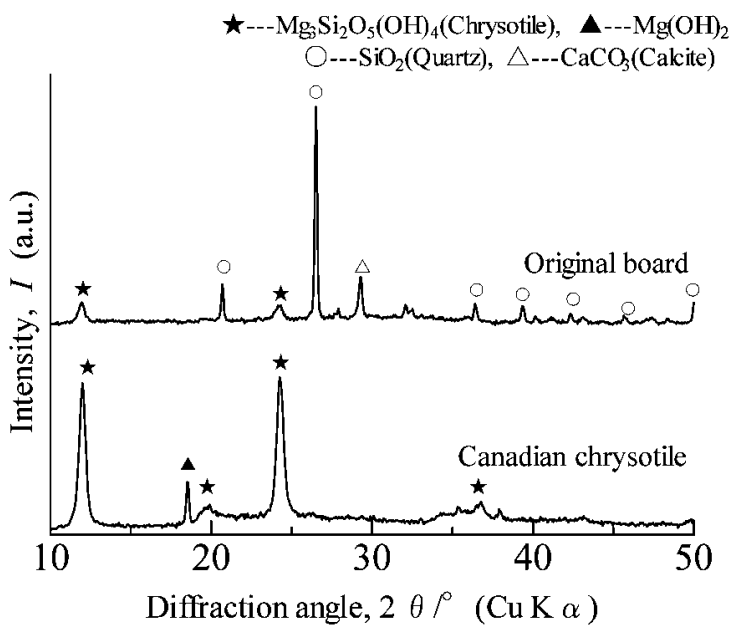

Fig. 2. XRD patterns of Canadian chrysotile and the chrysotile-containing cement board.

しての結晶相は結晶性が低いため回折線強度が小さく，ほとん ぞ同定できなかった。これはセメント板が長年に中性化（炭酸 化）の作用を受けたことによると考えられる4).このクリソタ イル結晶の回折線の有無が, 化学組成としてクリソタイルの存 在の有無の指標として捉えることができる.

図 3 に， $600^{\circ} \mathrm{C}$ での保持時間を变えた試料を，粉砕せずその 表面をそのままXRD 分析した結果を示す，0 h 保持した場合 とは, $600^{\circ} \mathrm{C}$ 到達後, その温度で保持せずすぐに冷却した試 料であるが，その試料表面からはクリソタイルが検出された。 一方, 保持時間が $1 \mathrm{~h}$ の試料表面からは, クリソタイルを示す

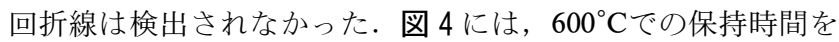
変えた試料内部の XRD 分析結果を示す. 試料内部の場合, 図 
3 の試料表面の場合には検出されなかった $1 \mathrm{~h}$ 保持の試料から も,クリソタイルを示す回折線は検出された．しかしながら保 持時間が $2 \mathrm{~h}$ になると, クリソタイルを示す回折線は検出され

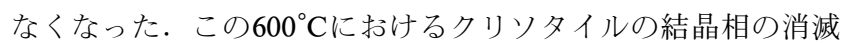
は, クリソタイルの脱水反応による非晶質化に伴うものである と考えられる3⿻,5).

図 5 には, 粉砕した非加熱処理試料と $600^{\circ} \mathrm{C} て ゙ ~ 0 h, 1 \mathrm{~h}$ 及び $2 \mathrm{~h}$ 加熱保持し，その後粉砕処理した試料のSEM 観察結果を示 す．セメント硬化体（C-S-H）の比重は結晶相の種類によって も違うが，打抢よそ2.2 $2.8 \mathrm{~g} / \mathrm{cm}^{3}$ の範囲にあり ${ }^{6)}$ ，これはク リソタイルの比重 $\left.2.4 \sim 2.6 \mathrm{~g} / \mathrm{cm}^{3} 7\right)$ とほとんど同じ值である. しかしクリソタイルは内部構造が中空を呈し ${ }^{8)}$, また図 $1(\mathrm{a})$ の

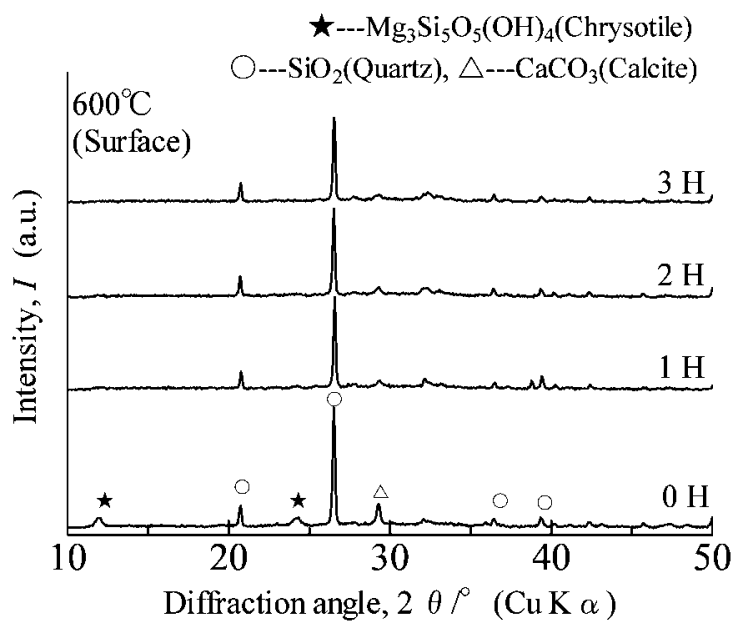

Fig. 3. XRD patterns of the surfaces of the chrysotile-containing cement board after heating at $600^{\circ} \mathrm{C}$ for $0-3 \mathrm{~h}$.
ように径が 0.2 数 $\mu \mathrm{m}$ の柔軟性をもった繊維状結晶でそれが束 なった形態をしている，そのため繊維間にはある程度の空間 (空気）を含むためにかさ比重は小さくなり, クリソタイルの 実際のセメント板に占める体積割合は, 重量に対する割合より 大きくなることが考えられる. したがって重量比で10２0\%含 まれる場合, クリソタイルが均一に分散していれば，セメント 板の微細組織のどこを観察してもクリソタイルが発見できる量 であるといえる. 実際に観察した図 5 の非加熱処理の試料の場 合では，多くの繊維状クリソタイル粒子が観察された。保持時 間を $0 \mathrm{~h}$ とした試料からは, ややその量は少なくなっているも のの, 繊維状の粒子は観察された。 $1 \mathrm{~h}$ 保持した試料からは, 絾維状の粒子はほとんどみられなくなり, ところどころに写真 のような比較的径の大きい繊維状粒子が観察された. 図 4 の回

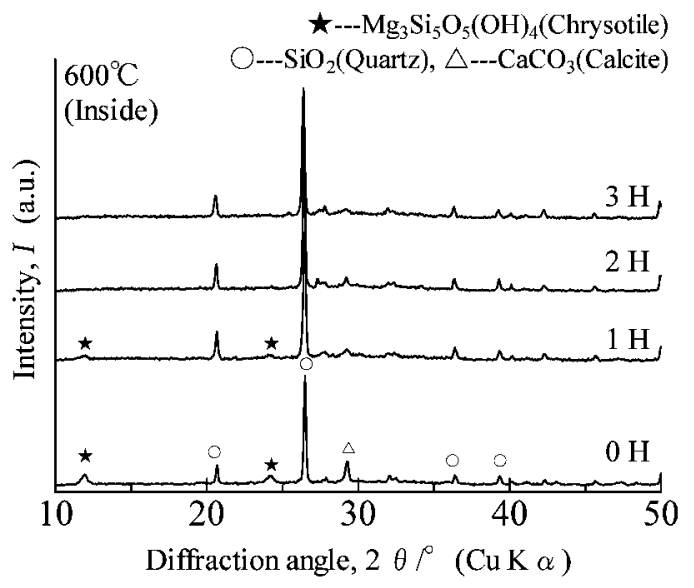

Fig. 4. XRD patterns of the inside of the chrysotile-containing cement board after heating at $600^{\circ} \mathrm{C}$ for $0-3 \mathrm{~h}$.
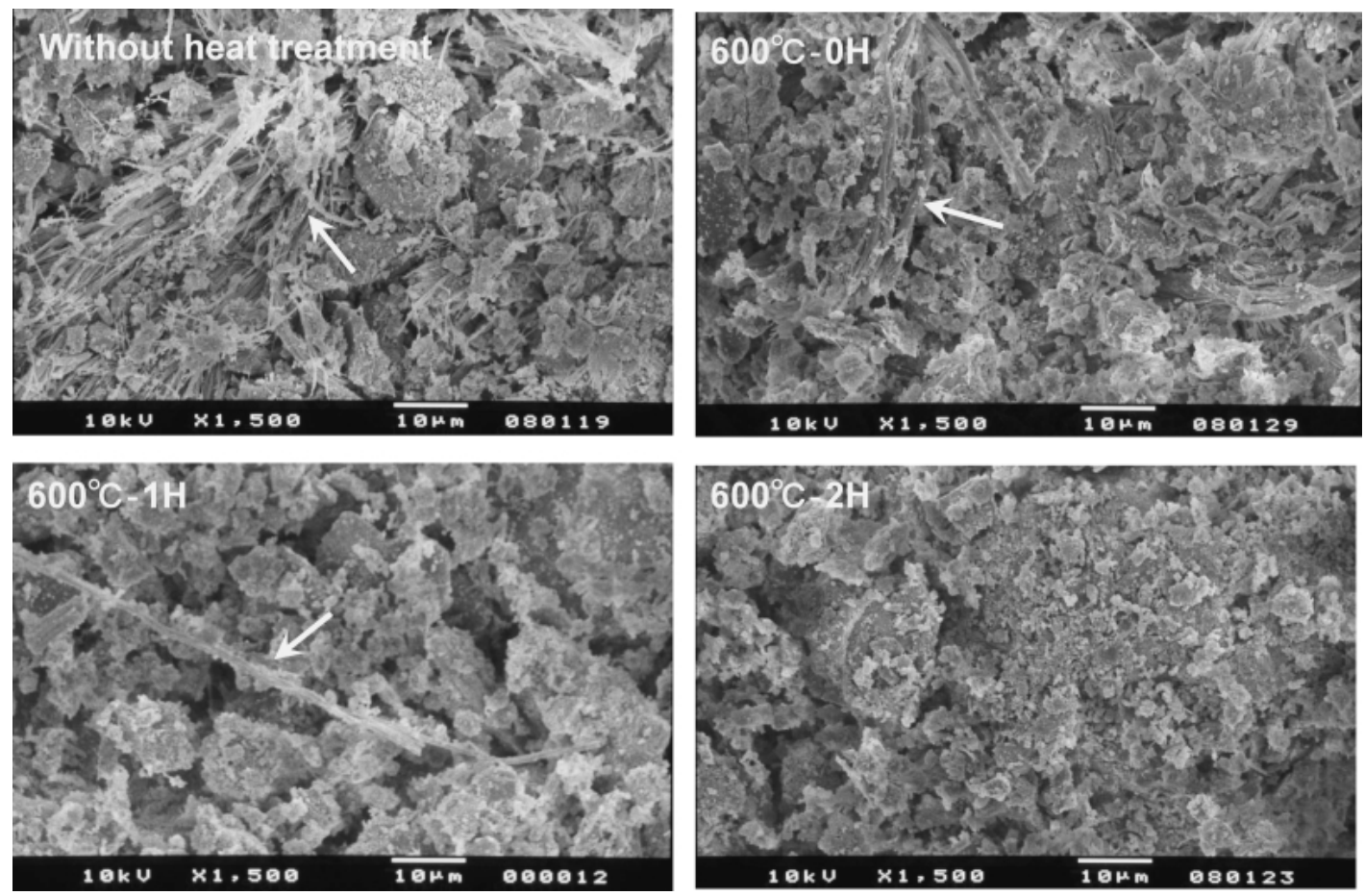

Fig. 5. SEM micrographs of the ground powder of the chrysotile-containing cement board with and without heating at $600^{\circ} \mathrm{C}$ for $0-2 \mathrm{~h}$. (Arrow indicates asbestos.) 
折パターンからも, $1 \mathrm{~h}$ 保持の条件ではクリソタイルの回折線 がわずかに検出されて抢り，この繊維状粒子がクリソタイルで あるとみられた。一方, $2 \mathrm{~h}$ 保持した試料からは, 径の比較的 大きなものまで含めてほとんど繊維状の粒子はみられなくなっ た. また, 図 4 の回折パターンでも $2 \mathrm{~h}$ 保持した条件ではクリ ソタイルの結晶相は検出されなくなっており，上記の観察結果 と矛盾しない。 以上の結果は, クリソタイル単体を対象とした 前報告 ${ }^{3)}$ の結論, すなわち, クリソタイルは $600^{\circ} \mathrm{C}, 2 \mathrm{~h}$ の加熱 処理によりほぼ脱水反応が完了し非晶質化すること, 及びその 場合に繊維状の形態を呈しているもののその粒子は非常に脆く なり, 乳鉢粉砕により容易に $1 \mu \mathrm{m}$ 以下に破壊できる, という 結果と一致する. 加えて, クリソタイルがセメントなど他成分 と共存すると, クリソタイル自身の反応性が活性化し, 脱水反 応の促進, 反応に伴う形態の消隇や, 残った針状を有する粒子 の脆化が促進した可能性も考えられる.

以上の結果から, クリソタイルを含有するセメント板を 600 ${ }^{\circ} \mathrm{C} て ゙ 2 \mathrm{~h}$ 加熱し，その後粉砕処理することで, 内包されたクリ ソタイルを組成的にも構造的にも破壊できることを明らかと し，クリソタイルを無害化できる有効な技術となり得ることを 確認した.

\section{4. まとめ}

アスベスト単体での繊維状形骸を消滅させる研究結果を踏ま え, 本研究では, セメント板中に含まれるアスベストの無害化 への応用展開を図った.クリソタイル（白石綿）を質量比で 10
〜 20\%含有する厚さ $5 \mathrm{~mm}$ のセメント板を $600^{\circ} \mathrm{C} て ゙ 2 \mathrm{~h}$ 加熱保 持することにより, セメント板中に内包された状態でもクリソ タイルの化学組成は失われた. 更にその後セメント成分もろと も粉砕することで, $1 \mu \mathrm{m}$ 以下という針状粒子が確認できない までに元のクリソタイルの繊維状の形態は破壊された.

付 記この研究は, (株)アイジ一技術研究所 (山形県東根市) の資金協力により行われたものである.

\section{References}

1) Yokoyama, K., "Sekimen·Zeoraito no Subete," Ed. by Miyake, H., Nippon Kankyo Eisei Center (1987) [in Japanese].

2) Stanton, M. F., Layard, M., Tegeris, A., Miller, E., May, M., Morgan, E. and Smith, A., J. Nat. Canc. Inst., Vol. 67, pp. 965-975 (1981).

3) Hashimoto, S. and Yamaguchi, A., J. Ceram. Soc. Japan, Vol. 113, pp. 312-316 (2005) [in Japanese].

4) Kobayashi, K., "Concrete Kozobutsu no Soki Rekka to Taikyusei Shindan," Ed. by Morikita, H., Morikita Shuppan (1991) pp. 132-134.

5) Kokai-Tokkyo-Koho, Hei 5-293457 [in Japanese].

6) Arai, Y., "Semento no Zairyo Kagaku," 2nd ed., Ed. by Sakuma, Y., Dainippon Tosho (1991) pp. 140-148.

7) Winson, R. W., "Asbestos," 4th ed., Ed. by Lefond, S. J., Industrial Minerals and Rocks, American Institute of Mining, Metallurgical and Petroleum Engineers (1975) pp. 384-385.

8) Yada, K., Acta Cryst., Vol. 23, pp. 704-707 (1967). 